\title{
Impact of liquidity, leverage, inflation on firm profitability an empirical analysis of food sector of Pakistan
}

\author{
Maria Rasheed Awan \\ Master of Business Administration Foundation University Rawalpindi Campus New Lalazar, Rawalpindi Cantt. \\ Pakistan
}

\begin{abstract}
This study focused on investigating the collision of leverage, liquidity and inflation on firm's profitability of the food industries of Pakistan. That is why, three self-sufficient variables its is independent, i.e. leverage, inflation and also liquidity were being taken into consideration to spot the impact on dependent variable, i.e. firm's earning (profitability). The population chosen due to this certain study is usually foodstuff sector involving Pakistan. That research come to the conclusion that there's a solid bad negatively relating to the changing control leverage, liquidity, inflation and also the firm's earning(profitability)..Liquidity ratios are insignificant relationship with return on asset and return on equity. Debt ratios are negatively associative with return on assets and return on sales. Profitability ratios are positively associative with return on assets and return on equity. However carefully assessments have to be taken in relation of firm's profitability variations, by keeping in vision the importance of leverage and liquidity of the firms, which in turn would help in proposing financial changes in future.
\end{abstract}

Keywords: Liquidity, Inflation, Market, Organizations profits, Ratios, Leverage.

\section{Introduction:}

The idea of liquidity signifies their education to help which often a property as well as stability can be purchased as well as available already in the market without impacting on the asset's selling price. Liquidity is usually characterized by a top amount of buying and selling exercise. Possessions that can be simply purchased as well as available are usually called fluid assets.

The ability to convert a property to help income easily generally known as "marketability.

There isn't a distinct liquidity system; nonetheless, liquidity is normally worked out through the use of liquidity ratios. Examples belongings which have been effortlessly converted into cash include blue chips as well as dollars current market. While leverage suggests the usage of several economic tools or borrowed funds, for example border, to raise the particular potential come back of investment decision or the number of credit card debt accustomed to finance a new company's belongings. A company using a lot more credit card debt compared to money is actually considered to be extremely leveraged. Leverage can be normally utilizing in real estate investment orders by making use of mortgage loans to order your house. Influence assists the entrepreneur and also the organization to invest or even run. However, the idea is included with better chance. In the event a great entrepreneur employs control to invest and also the expenditure goes against the entrepreneur, their burning is a lot higher than the idea would have been recently when the expenditure can't be leveraged, an organization will use control to go to produce shareholder success, yet in the event that the idea isn't able to do, Thus interest expense are also credit score chance of default terminated shareholders value though inflation may be the fee when the final level of prices intended for merchandise and also solutions can be soaring, and also, consequently, buying electrical power can be decreasing. Central banks make an effort to cease significant inflation, together with significant deflation, in an attempt to maintain the increased development of prices to your minimum. Firm Profitability investigates how a country's financial system affects the relationship between the in progress R\&D investments and the firm's future profitability. All of them examined the role of the financial environment in the stock market assessment of R\&D expenditure and not compulsory that assessment differences between market-based and bank-based financial systems are based on the information irregularity between a firm and its' investors.(Karjalainen, 2008). Maintenance collision on business performance aspects such as productivity and profitability has greater than before. (Alsyouf, 2007).

The resource based vision is that organizational structures and management practices correspond to the main source of heterogeneity in performance between firms (Goddard et al. 2009).The purpose of working capital management is to make certain that the firm is intelligent to meet its operating expenses and also stay behind in a position to compensate short-term obligations as and when they go down due (Ukaegbu, 2013).We have a well-known assumption there's a close link between organization growth and also profitability. However, most of the earlier reports on organization growth and also earnings happen to be executed with no joint relations (Jang \&Park, 2011). 
Profitability in a straight line impacts on the compensation of a manager since the concluding depends on the presentation of the firm. It is also a key variable for shareholders and investors in any industry and it has been comprehensively used to forecast firm's economic failure (Reynaud \& Thomas, 2013).Profitability, considered by gross profits-to-assets, has approximately the same power as book to-market predicting the cross section of average returns. Profitable firms produce considerably higher returns than unprofitable firms, regardless of having significantly higher assessment ratios (Marx, 2013).Privatization possesses enticed strong attentiveness within the public alternative as well as corporate governance literature due to professed link involving the title structure of businesses as well as agency efficiency, while using second item as a possible standard component active business efficiency as well as economy-wide development(Arin\&Ulubasoglu, 2009).

The majority of the business activity was executed simply by proprietorship's, partners or even closed corporations. Within these kinds of business group, a tiny as well as carefully hooked up gang of persons belonging to the very same family or even cooperating running a business regarding extensive cycles runs the particular firm as well as gives its gains (profits). (Lauterbach\&Vaninsky,1999). The theoretical writing on the relation between age and productivity is uncertain. On the one hand, several theories put it to somebody that older workers are more productive. (Lallemand\&Rycx, 2009).

Test results give confirmation that block investment effect differs not only connecting state versus legal person ownership, but also between ownership by financial versus non-financial.

\section{Literature review:}

In previous studies these variables are widely used to determine the firm's profitability. Thus we conduct our study with these variables and explain each variable with its previous studies.

Inflation:

"Inflation is a general increase in the money supply".

Inflation affects the whole economy of the countries. This shows that inflation was very dangerous for all countries. In short run there was inverse relationship of inflation between unemployment, increase in inflation leads to decrease in unemployment and vice versa (Katria, 2010).Understanding just what inflation charge to be able to strive for was in addition severely significant since a lot of central banking companies have followed conventional statistical inflation ambitions during the last handful of decades (Billi \&Kahn, 2008).

If inflation has real economic belongings, then Governments can influence economics performance all the way through monetary policy (Hassan et, al. 2011).In a forecast context, projections of overall consumer price inflation often converge to recent values of inflation measured from consumer prices apart from food and energy prices (Kiley, 2008).Interest rate is used to control the inflation rate because when then prices of products become high it's discourage the customers. This situation is not good for economy. So we boost the short term interest rate to diminish their inflation rate (Alverz et al 2001).

This particular general opinion improves an attractive policy problem involving the amount involving inflation is actually an excessive amount; which is, the amount inflation impedes monetary increase? While work with modeling the type involving partnership in between inflation and also monetary increase is actually underneath development, a tremendous volume of literary works for this question was offered(Mubarik, 2005).Inflation was the most important issue of developing or under developing countries .Many economies are swirly effected with inflation .Inflation effect the financial ratios (Ilter, 2012).Among its quite a few possible uses, selling price index designed with on the net data enable you to get replacement inflation estimates in nations exactly where public estimates get mislaid their own stability(Cavallo, 2012).

According to Good friend, Fed officials understand swift increases in long-term bond rates as the product of rising inflationary anticipation, reflecting a decline in the credibility of their struggle against inflation (Ireland, 1996). The inflation risk quality that delivers a "cleaner" measure of investors' inflation prospect implanted in government bond prices. To keep the analysis convenient, liquidity risk premia are not considered unambiguously here (Hordahl, 2008).In case intermediate-level macroeconomics lessons are usually to work obtain learners take into consideration beginning coverage troubles, you should give them a number of benefits for the implication inflation targeting offers for macroeconomic functionality (Walsh, 2002).

The relationship between inflation and stock market returns in short run as well as in long run. The basic question we effort to give an suitable answer through the investigation of the above relationship was whether the stock market has been a protected place for investors in Pakistan from 1971 to 2006 (June);( Akmal, 2007). The amalgamation of the negative relation between interest rates and stock prices and the positive relation between inflation and interest rates has led some researchers to terminate that there should be a causal negative relation from inflation rates to stock prices (Farsio\&Fazel, 2008).

For example, alluding for you to the truth that the actual stock market business presentation is dependent upon not merely the issue on the fiscal marketplaces and also macroeconomic permanence, nevertheless, the actual outer marketplaces also, robust evidences recommend volatility clustering, which is, 
huge (small) bumps have a tendency to proceed behind equivalent large (small) bumps. This is due to real economical parameters which gain from these kind of interactions have a tendency to show dedication; end result, inflation, rate, alternate rate, oil rates etc. (Aliyu, 2009).Large inflation fee anticipate low increase fee involving (real) complete fiscal activity. As fiscal activity increase is usually slow down, the increase fee in the desire regarding true money account balances is also supposed to reduce, most important a great increase inside long term predicted and also current inflation (Balduzzi, 1995).

\section{Firm Profitability:}

"Profit would be the financial give back or even compensate of which business people aim to attain to help mirror danger they get. Considering the fact that almost all business people commit to make any give back, the particular profit earned with a company enable you to determine the particular achievements of these expenditure."

Modern management coverage on its company's performance is prejudiced by individuals' ethical considerations. Stakeholders' philosophies have constant to modify over the last 75 years affecting coverage systems for company's coverage information on the inside and on the outside. These primary changes in philosophy have affected how information is conveyed (Rodgers \&Gago, 2004).Most of us review the actual regards between immovability in the charitable organization's surroundings and its particular panel structure along with the collision on this regards about organizational performance from the points of views involving each FROM as well as RDT. The actual collision involving panel characteristics about organizational performance is usually background (Callen et, al. 2010).

In the world of finance, professionals struggle to capitulate the highest rate of return on their investment, although at the same time minimizing their financial risk (Pearson, 2009). Conclusiondeclare that talk about ownership, legal person ownership, board dimensions, as well as supervisory board meetings usually are unenthusiastic relevant to the actual earnings of such corporations, whilst aspects along with ownership attentiveness, dangerous ownership, self-sufficient directors, board meetings, as well as supervisory board dimensions have zero influences (Shan \&Xu, 2012).Test results give confirmation that block investment effect differs not only connecting state versus legal person ownership, but also between ownership by financial versus non-financial institutions. Preponderance ownership by state (legal person)-dominated financial institutions was establish to have a negative (positive) impact on firm performance (Zhao, 2003).

\section{Firm Leverage:}

"The use of different monetary instruments or maybe borrowed investment capital, including margin, to increase the likely come back of investment".

This paper aims to explore the spatial allotment of the financial system by exploring the impacts of the development level of a municipality's financial system over its neighborhoods (Croccoet, al. 2010).This article studies the belongings of financial structure on the growth of physical capital gathering. Several theoretical works have future that banks are better than stock markets in funding capital investment (Rioja \&Valev, 2012).Financial accounting is particularly useful for illustrating the strengths and weaknesses of an enterprise and for showing an enterprise's development prospective. Information about an economic unit was important to those paying attention, such as the state, credit organizations, and investors, and might be used by its executives in financial decision making (Diakomihalis, 2011).

The empirical proof offers help for your belongings involving taxes; asymmetric data in addition to measurement not really obligatory within the theoretical materials in addition to discards the effects involving organization prices plus the pecking purchase idea. It also demonstrates the capital construction choice in these kind of firms has not been produced in the essentially distinct approach when compared with in big firms(Hol\&Wijst, 2008).Correspondingly depending on the stages of economic development there exists specific industrial structure. The financial system would complete efficiently when the financial structure matches the industrial structure of any economy (Sethi\& Kumar, 2012).In the consequences of the bankruptcy of a most important periodicals vendor, serials acquisitions changed forever. The resulting interference in the subscription process engaged librarians, publishers and vendors for over 2 years, moving thousands of libraries and costing millions of dollars (Wiegand, 2005).

This particular paper recommends a single locate connected with mechanisms of which scarves financial globalization procedures in order to local characteristics connected with financial supplement or maybe trying to keep out there. Specifically, this specific paper explores the particular globally re-examination connected with financial firms' tactics which has accompanied financial globalization(Dymski, 2005). This specific document deals one of the problem regarding simultaneity joining this firm's purchases and monetary design inside circumstance regarding self-motivated marketing the location where the strategy of info diffusion that connections this earnings from the corporation to be able to the share price just will take element slowly, spectacular to market blemishes and diverging rewards joining investors and operators (Mazzoli, 2005). 
Generally there looks like it's a agreement that the current corporate and business investment capital structure is usually disturbed understanding that a healthy along with balanced financial structure seemed to be a precondition for continual along with continual expansion in the non-public industry (Choi, 1987). The writing on financial structure classifies financial systems into bank-based and market-based. This distinction between different financial systems and their relative significance to economic growth has been the focus of theoretical discuss for over a century (Arestis et, al. 2010).Facts due to this then lie in the growth regarding technology, any difference concerning creation in addition to marketing and advertising in included businesses, yet, certainly, in marketplace signs which in turn regularly knowledgeable internet marketers that field of expertise proved helpful. Throughout attracting such a conclusion we all change in essence through past interpretations on the climb in addition to fall regarding Lancashire textiles.(Higgins \& Toms, 1997).Focusing on economic reasons that substantiate privatizations, we investigate whether there are differences connecting recently privatized stateowned enterprises (SOEs) and private firms in their profitability, leverage and efficiency all through the period 1999-2002. Differing to previous studies, our results explain that privatized firms were not less efficient than firms with private ownership (Arcas\&Bachiller, 2008).In difference, growth histories were not understandable determinants of financial structure. Consequences also recommend that leverage strategies were clearer in lowknowledge industries, in firms with higher opportunity of future performance, and in businesses with additional balanced financial structures (Thornhillet, al. 2004). We all identify of which although levered companies have been frequently far more worthwhile compared to unrelieved companies, earnings decreases the debt rate regarding levered companies. We all don't identify of which corporation dimension impacts the administrative capital structure regarding foreign companies. A serious deficiency of liquidity means that the firm was missing ability to pay its current debts or other obligations. This may, in turn, result in the compulsory sale of investments and properties and, in its most severe condition, to liquidation and bankruptcy (Wang, 2002).Liquidity administration, particularly on the available about on the global financial meltdown, has developed into significant method to obtain trepidation regarding business managers seeing that bank loans have gotten very costly to preserve due to contraction connected with both neighborhood as well as global financial market place plus the unwillingness on the open to purchase the particular talk about connected with businesses follow up towards the crash on the investment capital market place(Ajao et, al. 2012).

The dependent variable, return on total assets was used as a determine of profitability and the relation connecting working capital management and corporate profitability was investigated for a sample of 58 small manufacturing firms, with panel data analysis for the period 1998 - 2003 (Padachi, 2006).Elected a sample of 94 Pakistani firms listed on Karachi Stock Exchange for a period of 6 years from 1999 - 2004.The consequences show that there was a strong negative relationship connecting variables of the working capital management and profitability of the firm. Negative relationship connects liquidity and profitability.

The study defenses the fact that efficient liquidity management can considerably influence returns on capital employed by a bank and as well impact positively on the bank's profitability and consequently its stability ( Agbada\& C, 2013). Profitability of bank, although credit risk and liquidity risk will reason to decrease in the bank's profitability. Consequently regarding to the goal of research, the consequences generally demonstrate that liquidity risk will reason to decrease in the performance of bank (Tabari et, al. 2013).

The most important liquidity ratio was regressed on the profitability ratio. There was a feeble positive relationship connecting the liquidity and the profitability of the listed banks. Sufficient liquidity helps the bank minimize liquidity risk as well as financial crises (Lartey et .al. 2013). The current examine goals to disclose their relation between liquidity along with productivity so that every single firm must preserve that marriage at the same time as with conducting day to day procedures. Therefore it is finished in which liquidity ratios have an impact on the productivity ratios (Saleem\&Rehman, 2011).

This well-organized supervision involving doing work money had been critical in the peak involving check out involving in concert liquidity in addition to success. Bad supervision involving doing work money implies that resources were being with no lead to tied up inside nonproductive resources for that reason rapidly declining liquidity and in addition rapidly declining the ability to invest in profitable resources(Ekanem, 2010). The healthy and strong implication of the turnover ratio suggests that this characteristic variable may be connected to some other form of liquidity procedures and or trading costs. Additional investigation of the interactions connecting these variables and the test, using alternative liquidity procedures such as the ones projected were a subject for future research.

(Tsalavoutas\& Evans, 2010).A firm may have to impediment payments, sell assets, relinquish profitable investment opportunities, or get hold of temporary financing at critical terms if its skill to meet these cash requirements (Emery \& Cogger,1982).

liquidity and the various conduct in which firms in the real and the financial sectors manage their liquidity requirements so as to be intelligent to carry out production and investment plans effectively without being held back by impermanent liquidity shortages. Numerous key decisions impact a corporation's future ability to advantage itself of financial funds (Holmstrom\& Tirole, 2000). Thus, the 
manager of your small business is at some sort of predicament involving obtaining almost all wanted trade-off between liquidity and productivity as a way to make best use of the worth of your company. Throughout thoughtful, all of us examined the relationship concerning firms' working funds and firms' efficiency (Abuzayed\& Jordan, 2011).

This specific paper supplies a type of the communication concerning risk-management practices and market place liquidity. Possibility management takes on any midsection position throughout institutional investors' allotment regarding cash to exchanging. Not simply really does chance management affect liquidity; liquidity be able to furthermore affect risk-management practices (Gaxrlean\& Pedersen, 2007). Liquidity chance could be categorized moreover while property liquidity chance or perhaps while financing liquidity chance. This specific short-term financing qualification makes liquidity chance throughout totaling to the cash flow chance in the past experienced from the agency (Tse\& Wong, 2011).

Model

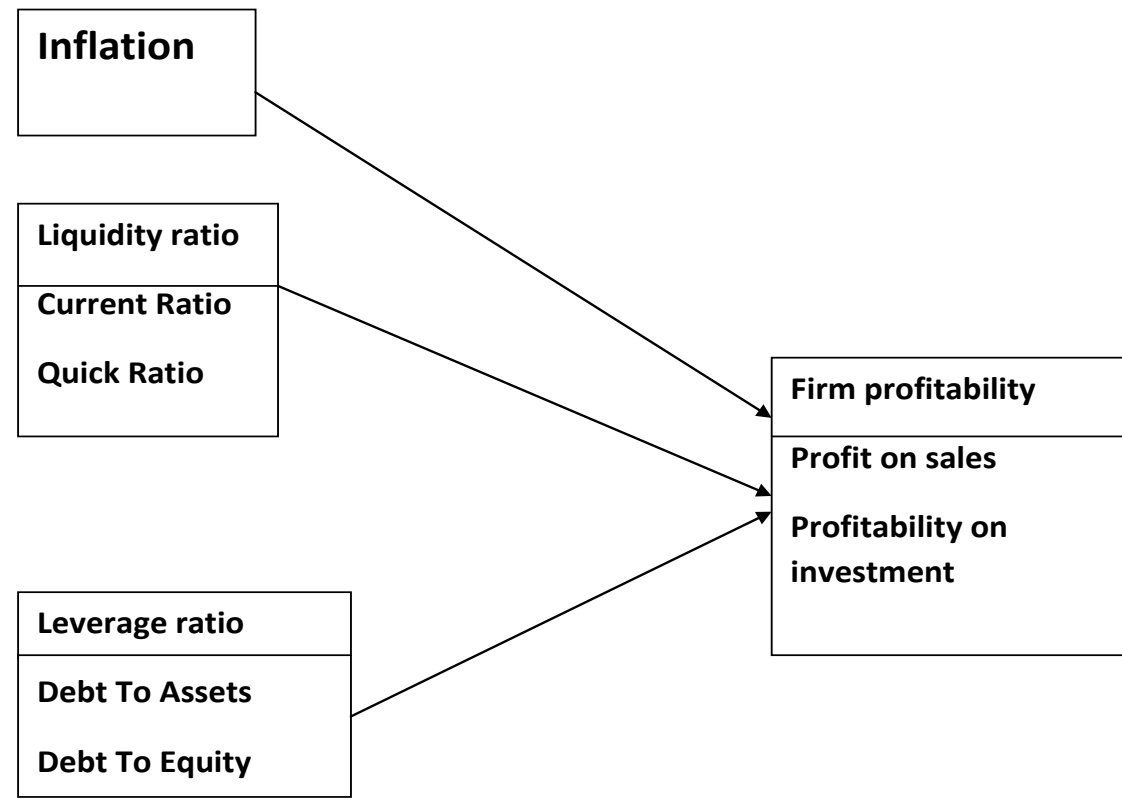

III. Research Methodology

The data chose for this research is in Financial Balance Sheets of food sectors of Pakistan. The data is obtained for six years (2006-2011) which has been published by State Bank of Pakistan. Expediency sampling may be utilized to find the companies which are why files had been readily available for the associated with study. The data obtained with this study was at use from Financial Balance Sheets in addition to yearly reports in the selected companies. Analysis of companies in food sectors of Pakistan is listed on the Karachi stock exchange (KSE). Fifty five companies have been taken having sample size 330. In paper, researchers have second-hand hypothetical deductive method in which hypotheses was attested through Statistical in nature. We were concluding regression, correlation and descriptive statistics results.

\section{Hypotheses}

H1: Inflation is significantly associated with the firm's profitability.

H1a: Inflation is positively associative with profit on sales.

$\mathrm{H} 1 \mathrm{~b}$ : Inflation is positively associative with profitability on investment.

H2: Liquidity is significantly associated with the firm's profitability

$\mathrm{H} 2 \mathrm{a}$ : Current ratio is positively associated with profit on Sales.

$\mathrm{H} 2 \mathrm{~b}$ : Current ratio is positively associated with profitability on investment.

H3c: Quick ratio is positively associated with profit on Sales.

H4d: Quick ratio is positively associated with profitability on investment.

H3: Leverage is significantly associated with the firm's profitability

H2a: Debt to assets is positively associated with profit on Sales.

$\mathrm{H} 2 \mathrm{~b}$ : Debt to assets is positively associated with profitability on investment.

H3c: Debt to equity is positively associated with profit on Sales.

H4d: Debt to equity is positively associated with profitability on investment. 


\subsection{Descriptive statistics}

\section{Result and discussion:}

\begin{tabular}{|l|l|l|l|l|l|}
\hline \multirow{3}{*}{ Debt Ratios } & Variables & Minimum & Maximum & Mean & Std. Deviation \\
\hline \multirow{5}{*}{ Liquidity Ratios } & DTA & 0 & 382.58 & 6.8355 & 42.69837 \\
\cline { 2 - 6 } & DTE & -360.8 & 242.84 & -0.2526 & 33.44066 \\
\hline Profitability Ratios & CR & 0 & 34.89 & 1.4399 & 3.30602 \\
\cline { 2 - 6 } & QR & 0 & 23.77 & 0.5767 & 2.14219 \\
\hline & NPM & -1538.46 & 641.35 & -4.1461 & 102.39702 \\
\cline { 2 - 6 } & OPM & -15.38 & 6.41 & -0.0415 & 1.02397 \\
\cline { 2 - 6 } & GPM & -25.17 & 1 & -0.005 & 1.46959 \\
\cline { 2 - 6 } & ROA & -110.14 & 122.86 & 5.1114 & 20.9665 \\
\cline { 2 - 6 } & ROE & -1881.86 & 2454.76 & 21.0519 & 194.93647 \\
\hline Inflation & INF & 7.6 & 20.29 & 12.5419 & 4.27199 \\
\hline
\end{tabular}

$\mathrm{N}=330$

Independent variable: Debt to assets (DTA), Debt to equity (DTE), Current ratio (CR), Quick ratio (QR), Inflation (INF)

Dependent variable: Net profit margin (NPM), Operating profit margin (OPM), Gross profit margin (GPM), Return on assets (ROA), Return on equity (ROE),

In above table shows that the debt to assets is independent variable and its minimum value is 0 and its maximum value is 382.58 .the mean of debt to assets is 6.8355 and its standard value is 42.69837 . Debt to equity is independent variable and its minimum value is -360.8 and its maximum value is 242.84 . The mean of debt to equity is-0.2526 and its standard value is 33.44066.Both of these are called debt ratios. Current ratio is independent variable and its minimum value is 0 and its maximum value is 34.89 . The mean of current ratio is 1.4399 and its standard value is 3.30602.Quick ratio is independent variable and its minimum value is 0 and its maximum value is 23.77 .The mean of quick ratio is 0.5767 and its standard value is 2.14219 . Both of these are liquidity ratios. Net profit margin is dependent variable and its minimum value is -1538.46 and its maximum value is 641.35 .The mean of net profit margin is -4.1461 and its standard value is 102.39702 . Operating profit margin is dependent variable and its minimum value is -15.38 and its maximum value is 6.41 .The mean of operating profit margin is -0.0415 and its standard value is 1.02397 . Gross profit margin is dependent variable and its minimum value is -25.17 and its maximum value is 1 . The mean of gross profit margin is -0.005 and its standard value is 1.46959. Return on assets is dependent variable and its minimum value is -110.14 and its maximum value is 122.86 .The mean of return on assets is 5.1114 and its standard value is 20.9665 . Return on equity is dependent variable and its minimum value is -1881.86 and its maximum value is 2454.76 .The mean of return on equity is 21.0519 and its standard value is 194.93647.All of them are called profitability ratios. Inflation is independent variable and its minimum value is 7.6 and its maximum value is 20.29 .The mean of inflation is 12.5419 and its standard value is 4.27199 .

\subsection{Correlation}

\begin{tabular}{|l|l|l|l|l|l|l|l|l|l|}
\hline Variables & DTA & DTE & CR & QR & NPM & OPM & GPM & ROA & ROE \\
\hline DTA & 1 & -0.004 & -0.065 & -0.041 & 0.007 & 0.007 & 0.002 & $-.418^{* *}$ & -0.016 \\
\hline DTE & -0.004 & 1 & 0.01 & 0.004 & 0.012 & 0.012 & 0.012 & 0.033 \\
\hline CR & -0.065 & 0.01 & 1 & $.982^{* *}$ & $-.347 * *$ & $-.347 * *$ & $-.320^{* *}$ & 0.035 \\
\hline QR & -0.041 & 0.004 & $.982^{* *}$ & 1 & $-.305^{* *}$ & $-.305^{* *}$ & $-.272^{* *}$ & -0.012 & -0.017 \\
\hline NPM & 0.007 & 0.012 & $-.347^{* *}$ & $-.305^{* *}$ & 1 & $1.000^{* *}$ & $.895^{* *}$ & $.288^{* *}$ & 0.087 \\
\hline OPM & 0.007 & 0.012 & $-.347^{* *}$ & $-.305^{* *}$ & $1.000^{* *}$ & 1 & $.895^{* *}$ & $.288^{* *}$ & 0.087 \\
\hline GPM & 0.002 & 0.012 & $-.320^{* *}$ & $-.272^{* *}$ & $.895^{* *}$ & $.895^{* *}$ & 1 & 0.088 & 0.029 \\
\hline ROA & $-.418^{* *}$ & 0.033 & 0.035 & -0.012 & $.288^{* *}$ & $.288^{* *}$ & 0.088 & 1 & $.203 * *$ \\
\hline ROE & -0.016 & $-.320^{* *}$ & -0.014 & -0.017 & 0.087 & 0.087 & 0.029 & $.203^{* *}$ & 1 \\
$*$
\end{tabular}

$* *$ indicates 5 per cent level of significance. $\mathrm{N}=330$

Independent variable: Debt to assets (DTA), Debt to equity (DTE), Current ratio (CR), Quick ratio (QR), Inflation (INF)

Dependent variable: Net profit margin (NPM), Operating profit margin (OPM), Gross profit margin (GPM), Return on assets (ROA), Return on equity (ROE).

In above table show the results of debt to assets are independent variable and its insignificant relation with net profit margin. It insignificant relation operating profit margin, its insignificant relation with gross profit margin, its strongly negative significant relation with return on assets and its negative insignificant relation with return 
on equity. Debt to equity is independent variable and its insignificant relation with net profit margin. It insignificant relation operating profit margin, its insignificant relation with gross profit margin, its insignificant relation with return on assets and its strongly negative significant relation with return on equity.

Current ratio is independent variable and its strongly negative significant relation with net profit margin. It's strongly negative significant relation operating profit margin, its strongly negative significant relation with gross profit margin, its insignificant relation with return on assets and its negative insignificant relation with return on equity. Quick ratio is independent variable and its strongly negative significant relation with net profit margin. It's strongly negative significant relation operating profit margin, its strongly negative significant relation with gross profit margin, its negative insignificant relation with return on assets and its negative insignificant relation with return on equity. Net profit margin is dependent variable and its insignificant relation with net profit margin. It's strongly positive significant relation operating profit margin, its strongly positive significant relation with gross profit margin, its strongly positive significant relation with return on assets and its insignificant relation with return on equity.

Operating profit margin is dependent variable and its strongly positive significant relation with net profit margin. It's insignificant relation operating profit margin, its strongly positive significant relation with gross profit margin, its strongly positive significant relation with return on assets and its insignificant relation with return on equity. Gross profit margin is dependent variable and its strongly positive significant relation with net profit margin. It's strongly positive significant relation operating profit margin, its insignificant relation with gross profit margin, its insignificant relation with return on assets and its insignificant relation with return on equity. Returns on assets are dependent variable and its strongly positive significant relation with net profit margin. It's strongly positive significant relation operating profit margin, its insignificant relation with gross profit margin, its insignificant relation with return on assets and its strongly positive significant relation with return on equity.

Return on equity is dependent variable and its insignificant relation with net profit margin. It's insignificant relation operating profit margin, its insignificant relation with gross profit margin, its strongly positive significant relation with return on assets and its insignificant relation with return on equity.

\subsection{Model summary}

1.3. Model summary
\begin{tabular}{|l|l|l|l|l|l|}
\hline GPM & R & R square & F & sig & t \\
\hline NPM & .391 & 0.153 & 14.646 & $.000^{*}$ & 4.643 \\
\hline OPM & .397 & 0.158 & 15.197 & $.000^{*}$ & 3.91 \\
\hline ROE & .397 & 0.158 & 15.197 & $.000^{*}$ & $.000^{*}$ \\
\hline ROA & .321 & 0.103 & 9.362 & $.000^{*}$ & 3.5 \\
\hline
\end{tabular}

$\mathrm{N}=330$

Dependent variable: Net profit margin (NPM), Operating profit margin (OPM), Gross profit margin (GPM), Return on assets (ROA), Return on equity (ROE).

In above table shows summary of dependent variables that is gross profit margin $\mathrm{R}$ is positively significant, $\mathrm{R}^{2}$ is insignificant, $F$ is insignificant, $t$ is insignificant, and it is positively significant. Net profit margin $R$ is positively significant, $\mathrm{R}^{2}$ is insignificant, $\mathrm{F}$ is insignificant, $\mathrm{t}$ is insignificant, and it is positively significant. Operating profit margin $R$ is positively significant, $R^{2}$ is insignificant, $F$ is insignificant, $t$ is insignificant, and it is positively significant. Return on equity $R$ is positively significant, $R^{2}$ is insignificant, $F$ is insignificant, $t$ is insignificant, and it is positively significant. Return on assets $R$ is positively significant, $R^{2}$ is insignificant, $F$ is insignificant, $\mathrm{t}$ is insignificant, and it is positively significant.

\subsection{Correlation}

\begin{tabular}{|l|l|l|l|}
\hline Variables & INF & ROA & ROE \\
\hline INF & 1 & 0.008 & $.148^{* *}$ \\
\hline ROA & 0.008 & 1 & $.203^{* *}$ \\
\hline ROE & $.148^{* *}$ & $.203^{* *}$ & 1 \\
\hline$*$ in &
\end{tabular}

$* *$ indicates 5 per cent level of significance. $\mathrm{N}=330$

Independent variable: Inflation (INF)

Dependent variable: Return on assets (ROA), Return on equity (ROE).

In above table shows the relation of independent variable (INF) with dependent variables (ROA), (ROE) and results are insignificant relation with return on assets. It strongly positive significant relation with return on equity. Return on assets is dependent variable and its insignificant relation with return on assets. It strongly 
positive significant relation with return on equity. Return on equity is dependent variable and its strongly positive significant relation with return on assets. It is insignificant relation with return on equity.

\subsection{Model summary}

\begin{tabular}{|l|l|l|l|l|l|}
\hline $\begin{array}{l}\text { Model } \\
\text { summary }\end{array}$ & R & R square & F & Sig & t \\
\hline ROE & .148 & 0.022 & 7.389 & $.007^{*}$ & 2.718 \\
\hline ROA & .008 & 0 & 0.023 & $.880^{*}$ & 0.151 \\
\hline
\end{tabular}

$\mathrm{N}=330$

Dependent variable: Return on assets (ROA), Return on equity (ROE).

In above table shows return on equity $R$ is positively significant, $R^{2}$ is insignificant, and $F$ is in significant, $t$ is insignificant and positively significant. Return on assets $R$ is positively significant, $R^{2}$ is insignificant, and $F$ is in significant, $t$ is insignificant and positively significant.

\section{Conclusion}

In this study, we examined a sample of 55 companies in the food sector by using regression and correlation analysis to assess the determinants of profitability of the firms. The study utilized the data over the period 2006 to 2011. We have thus gathered strong evidence to show that liquidity, inflation leverage have a significant positive impact on profitability of the firms. The regression and correlation analysis performed in order to assess the relationship between leverage, inflation, liquidity and the firm's profitability. The study concluded that liquidity, leverage and inflation are directly positively associative on firm profitability.

Debt to assets strongly negative significant relation with return on assets. If debt to assets are increased return on asset decreased. It negative insignificant relation with return on equity. Debt to equity insignificant relation with return on assets. If debt of equity are increased and return on asset decreased. It strongly negative significant relation with return on equity. Current ratio insignificant relation with return on assets. If current ratio are increased and return on asset decreased. It negative insignificant relation with return on equity. If quick ratio increased return on asset decreased. It's negative insignificant relation with return on equity and if quick ratio is increased return on equity decreased. If net profit margin increased return on assets increased. It insignificant relation with return on equity. Operating profit margin strongly positive significant relation with return on assets. If operating profit margin return on asset increased. Gross profit margin insignificant relation with return on equity. If gross profit margin increased return on assets decreased. It insignificant relation with return on assets and its insignificant relation with return on equity. Return on assets insignificant relation with return on assets and its strongly positive significant relation with return on equity. If return on assets increased returned on equity also increased. Return on equity strongly positive significant relation with return on assets. If return on equity increased return on asset increased.

\section{Limitations and future directions}

Now days the food sectors of Pakistan is going through a very hard and dangerous time due to the current recession and other domestic and international crisis. In order to get the best results, the analysis of the descriptive statistics of the financial indicators has been executed. The descriptive statistics associated with the financial indicators of the division of food sector of positively correlation between the dependent and independent variables. The value of $\mathrm{R}$ square strengthened the influence of the leverage, inflation, liquidity on firm profitability, but the regressions built between the variables were positive in reflecting a positive relation. Further the researcher have research on impact of liquidity, leverage and inflation on GDP.

\section{Reference:}

[1]. Katria.S(2010). TRADE OFF BETWEEN INFLATION AND UNEMPLOYMENT.Proceedings of 2ndInternational Conference on Business Management (ISBN: 978-969-9368-06-6)

[2]. Billi.R, Kahn.G(2008). What Is the Optimal Inflation Rate? Federal reserve bank of Kansas city ,pp. 5-28

[3]. Alverz.Fet,al. (2001).Interest rate and inflation. The American economic review,vol.91, pp.219-225

[4]. Ilter.C(2012). Exploring the Effects of Inflation on Financial Statements through Ratio Analysis. International Journal of Business and Social Science, Vol. 3,pp. 154-162

[5]. Ireland.P(1996). Long-Term Interest Rates and Inflation: A Fisherian Approach. Federal Reserve Bank of Richmond Economic Quarterly, Volume 82/1,pp.21-35

[6]. Hordahl.P(2008). The inflation risk premium in the term structure of interest rates. BIS Quarterly Review, pp.23-38

[7]. Farsio.F\&Fazel.F(2008). Can Investors Use Inflation Data to Predict Stock Prices? International Conference on Applied Economics, pp.311-313

[8]. Karjalainen.P(2008). R\&D investments: The effects of different financial environments on firm profitability. J. of Multi. Fin. Manag.vol.18,pp.79-93

[9]. Alsyouf.I(2007).The role of maintenance in improving companies' productivity and profitability.Int. J. Production Economics.vol.105,pp.70-78 
[10]. Jang.S\&Park.K(2011).Inter-relationship between firm growth and profitability.International Journal of Hospitality Management .vol. 30,pp. 1027- 1035

[11]. Reynaud.A\&Thomas.A(2013).Firm'sprofitability and regulation in water and network industries:An empirical analysis.Utilities Policy .vol.24,pp.48-58

[12]. Marx.R(2013).The other side of value: The gross profitability premium.Journal of Financial Economics .vol.108,pp.1-28

[13]. Arin.K\&M.Ulubasoglu(2009).Leviathan resists: the endogenous relationship between privatization and firm performance.Public Choice .vol .140, pp. 185-204

[14]. Crocco et, al.(2010).The Spatial Structure of Financial Development in Brazil.Spatial Economic Analysis.vol. 5, pp181-202

[15]. Rioja.F\&Valev.N(2012).Financial structure and capital investment.Applied Economics. Vol. 44, pp.1783-1793

[16]. Sethi.P\&Kumar.B(2012).FINANCIAL STRUCTURE GAP AND ECONOMIC DEVELOPMENT IN INDIA.Journal of Business Economics and Management.pp.1-19

[17]. Qiu.M\&La.B(2010).Firm Characteristics as Determinants of Capital Structures in Australia.Int. J. of the Economics of Business.vol. 17, pp. 277-287

[18]. Wang.Y(2002).Liquidity management, operating performance, and corporate value: evidence from Japan and Taiwan.Journal of Multinational Financial Management. vol.12, pp. 159- 169

[19]. Lartey.V et, al.(2013).The Relationship between Liquidity and Profitability of Listed Banks in Ghana.International Journal of Business and Social Science .vol. 4 ,pp.48-56

[20]. Kubota.K\&Takehara.H(2010).Expected return, liquidity risk, and contrarian strategy: evidence from the Tokyo Stock Exchange.ManagerialFinance.vol. 36,pp.655-679

[21]. Emery.G\&Cogger,K(1982).The Measurement of Liquidity.Journal of Accounting Research.vol. 20,pp.290-303

[22]. Holmstrom.B\&Tirole.J(2000).Liquidity and Risk Management.Journal of Money, Credit and Banking. vol. 32,pp.295-319

[23]. Abuzayed.B\&Jordan.A(2011).Working capital management andfirms' performance in emerging markets: the case of Jordan.International Journal of Managerial Finance.vol. 8, pp.155-179

[24]. Gaxrlean.N\&Pedersen.L(2007).Liquidity and Risk Management. The American Economic Review.vol. 97,pp.193-197

[25]. Tse.M\&Wong.K(2011). LIQUIDITY RISK AND CORPORATE HEDGINGWITH FUTURES.Pacific Economic Review.vol.16,pp.229-235.

[26]. Akmal.M (2007). STOCK RETURNS AND INFLATION: AN ARDL ECONOMETRIC INVESTIGATION UTILIZING PAKISTANI DATA. Pakistan Economic and Social Review, Volume 45, pp. 89-105 